\section{Polyamine Concentration and Ethylene Evolution in Tomato Plants under Nutritional Stress}

\author{
Jinan Feng and Allen V. Barker \\ Department of Plant and Soil Sciences, University of Massachusetts, Amherst, \\ MA 01003
}

Additional index words. Lycopersicon esculentum, ammonium accumulation

Abstract. Polyamine accumulation in foliage was assessed in relation to ammonium accumulation and ethylene evolution in tomato (Lycopersicon esculentum Mill.) under nutritional stress. Nutritional stresses were induced in greenhouse-grown plants in quartz sand with an $\mathrm{NH}_{4}$-based solution or with $\mathrm{NO}_{3}$-based solutions without $\mathrm{P}, \mathrm{K}$, $\mathrm{Ca}$, or $\mathrm{Mg}$. Plants receiving $\mathrm{NH}_{4}$-based nutrition had higher putrescine and lower spermidine concentrations than plants receiving $\mathrm{NO}_{3}$-based nutrition. Adding $\mathrm{AOA}\left(10^{-5} \mathrm{M}\right)$ to the nutrient solution of plants receiving $\mathrm{NH}_{4}$-based nutrition suppressed putrescine accumulation but had no effect on spermidine; silver thiosulfate $\left(10^{-5} \mathrm{M}\right)$ had no effect on polyamine accumulation. Deficiencies had no consistent effect on polyamine accumulation relative to its accumulation under full-nutrition conditions, but adding AOA restricted putrescine and spermidine accumulation in all nutrient-deficient regimes. Foliar spermine accumulation was not affected by nutritional regime. Ammonium-based nutrition resulted in enhanced putrescine and ammonium accumulation and accelerated ethylene evolution rates relative to plants receiving $\mathrm{NO}_{3}$-based nutrition. All nutrient-deficient plants had higher ammonium accumulation, and all but P-deficient plants had higher ethylene evolution than those receiving full $\mathrm{NO}_{3}$-based nutrition. Although some variability occurred among treatments, an association among putrescine accumulation, ammonium accumulation, ethylene evolution. and stress-induced symptoms was apparent. Chemical name used: (aminooxy) acetic acid (AOA).

Polyamine accumulation is a response of plants to various environmental stresses (Slocum and Weinstein, 1990). Putrescine accumulation was reported in response to $\mathrm{K}$ and Mg deficiencies (Basso and Smith, 1974). The concentration of putrescine was enhanced and accompanied by increased ethylene evolution in tomato plants subjected to ammonium toxicity and $\mathrm{K}$ deficiency (Corey and Barker, 1989). We reported a significant relationship between ethylene evolution and ammonium accumulation in tomato plants (Feng and Barker, 1992). Ammonium and polyamine accumulation and ethylene evolution may be interactive processes that are initiated by environmental stress and promote stress-related symptom development.

The objective of this study was to investigate the relationship of ammonium accumulation, polyamine accumulation, and ethylene evolution to nutritional stresses induced by ammonium toxicity or nutrient deficiency.

'Heinz 1350' tomato plants were grown in the greenhouse in quartz sand in Spring 1990. After applying half-strength Hoagland's no. 1 solution daily for 1 week, plants received full-

Received for publication 6 Apr. 1992. Accepted for publication 3 Sept. 1992. The cost of publishing this paper was defrayed in part by the payment of page charges. Under postal regulations, this paper must therefore be hereby marked advertisement solely to indicate this fact.

'Current address: Dept. of Soil Science, North Carolina State Univ., Raleigh, NC 27695-7619. strength ammonium or nitrate nutrition, or nitrate nutrition without $\mathrm{P}, \mathrm{K}, \mathrm{Ca}$, or $\mathrm{Mg}$. In one experiment, plants receiving ammonium nutrition were grown with or without $\mathbf{1 0}^{-5} \mathrm{M}$ AOA or $10^{-5} \mathrm{M}$ silver thiosulfate (STS). In another experiment, plants on nutrient-deficient solutions were grown with or without AOA. When toxicity or deficiency symptoms were visible, $2 \mathrm{~g}$ of leaflets from the new fully expanded leaves were collected and extracted with $5 \%$ perchloric acid, and polyamine concentrations were measured by high-performance liquid chromatography (Flores and Galston, 1982). The tips, including one fully expanded leaf, were taken for ethylene determination by gas chromatography (Feng and Barker, 1992). Ammonium- $\mathrm{N}$ in the tip samples was extracted with a solution of $1 \mathrm{MKC} 1+0.02$ $\mathrm{M} \mathrm{CuSO}_{4}$ and analyzed by steam distillation (Bremner, 1965). All treatments were arranged in four randomized complete blocks.

Tomato plants appeared chlorotic 5 days after ammonium was supplied and were epinastic with upward leaf cupping 5 days later. Plants receiving ammonium and STS developed ammonium toxicity symptoms 3 days later than those without STS. AOA prevented ammonium toxicity but retarded plant growth (Table 1).

Ethylene evolution from plants treated with ammonium was suppressed significantly by applying AOA (Table 1). Plants treated with STS had lower ethylene evolution rates than those receiving ammonium only, but had higher rates than those receiving ammonium and
AOA. Increased ammonium accumulation corresponded with enhanced ethylene evolution. Putrescine concentration in plants receiving ammonium nutrition was significantly higher than that in plants receiving nitrate nutrition, and spermidine concentration in plants receiving ammonium nutrition was lower than that in plants receiving nitrate nutrition (Table 2). Applying AOA decreased putrescine and spermine concentrations in plants receiving ammonium nutrition, but STS had no effects relative to those apparent in plants receiving ammonium only.

Plants treated with nutrient-deficient solutions showed deficiency symptoms after 2 weeks of treatment, but plants that received AOA showed no distinct deficiency symptoms. Fresh weights of plants receiving AOA, however, were lower than those not receiving AOA (Table 3). Neither ethylene evolution enhancement nor ammonium accumulation was detected with any nutritional regime receiving AOA. However, applying AOA suppressed ethylene evolution from plants deficient in $\mathrm{K}, \mathrm{Ca}$, or $\mathrm{Mg}$ and ammonium accumulation in plants deficient in $\mathrm{Ca}$ or $\mathrm{Mg}$. Supplying AOA decreased the sum of putrescine, spermidine, and spermine accumulation in the stressed plants. Based on individual polyamine concentrations (Table 4), the relative sums in the deficient regimes without AOA compared to those with AOA were (nanomoles per gram of dry weight) $\mathrm{P}, 1503$ vs. $1178 ; \mathrm{K}, 2374$ vs. $1740 ; \mathrm{Ca}, 1291$ vs. 1026 , and $\mathrm{Mg}, 2140$ vs. 1254.

Putrescine, spermidine, and spermine are often detected in stressed plants. These polyamines are considered to he involved in some plant growth and development processes (Galston et al., 1990). Polyamines may help protect plants against stress, or they may be

Table 1. Fresh weight, ethylene evolution, and ammonium accumulation as affected by form of $\mathrm{N}$ nutrition and by AOA or silver thiosulfate(STS).

\begin{tabular}{lccc}
\hline & \multicolumn{3}{c}{ Measurement $^{z}$} \\
\cline { 2 - 4 } & $\begin{array}{c}\text { Fresh } \\
\text { shoot wt } \\
(\mathrm{g} / \text { pot })\end{array}$ & $\begin{array}{c}\text { Ethylene } \\
\text { production } \\
\left(\text { nliter. }{ }^{-1} \cdot \mathrm{h}^{-1}\right)\end{array}$ & $\begin{array}{c}\text { Ammonium } \\
\text { conch } \\
(\mu \mathrm{g} \mathrm{N} / \mathrm{g})\end{array}$ \\
\hline $\mathrm{NO}_{3}$ & $103 \pm \overline{7}$ & $2.5 \pm 0.1$ & $33 \pm 1$ \\
$\mathrm{NH}_{4}$ & $65 \pm 4$ & $32.1 \pm 6.5$ & $193 \pm 7$ \\
$\mathrm{NH}_{4}+\mathrm{AOA}$ & $45 \pm 2$ & $5.6 \pm 0.2$ & $58 \pm 10$ \\
$\mathrm{NH}_{4}+\mathrm{STS}$ & $54 \pm 3$ & $20.0 \pm 3.2$ & $127 \pm 9$ \\
\hline
\end{tabular}

${ }^{\mathrm{z}}$ Mean followed by \pm se. Ethylene evolution and ammonium accumulation are expressed on a freshweight basis.

Table 2. Concentration of putrescine, spermidine, and spermine as affected by form of $\mathrm{N}$ nutrition and by AOA or silver thiosulfate (STS).

\begin{tabular}{lccc}
\hline & \multicolumn{3}{c}{$\begin{array}{c}\text { Measurement } \\
\text { (nmol/g dry wt) }\end{array}$} \\
\cline { 2 - 4 } Treatment & Putrescine & Spermidine & Spermine \\
\hline $\mathrm{NO}_{3}$ & $444 \pm 96$ & $1107 \pm 185$ & $302 \pm 85$ \\
$\mathrm{NH}_{4}$ & $1595 \pm 273$ & $824 \pm 85$ & $300 \pm 51$ \\
$\mathrm{NH}_{4}+\mathrm{AOA}$ & $542 \pm 155$ & $848 \pm 212$ & $173 \pm 85$ \\
$\mathrm{NH}_{4}+$ STS & $1427 \pm 477$ & $736 \pm 220$ & $281 \pm 85$ \\
\hline
\end{tabular}

${ }^{\mathrm{z}}$ Mean followed by \pm SE. 
Table 3. Fresh weight, ethylene evolution, and ammonium accumulation as affected by nutrient deficiency and AOA

\begin{tabular}{|c|c|c|c|c|c|c|}
\hline \multirow{3}{*}{$\begin{array}{l}\text { Nutritional } \\
\text { regime }\end{array}$} & \multicolumn{6}{|c|}{ Measurement ${ }^{z}$} \\
\hline & \multicolumn{2}{|c|}{$\begin{array}{l}\text { Fresh shoot wt } \\
\text { (g/pot) }\end{array}$} & \multicolumn{2}{|c|}{$\begin{array}{c}\text { Ethylene } \\
\left(\text { nliter } \cdot \mathrm{g}^{-1} \cdot \mathrm{h}^{-1}\right)\end{array}$} & \multicolumn{2}{|c|}{$\begin{array}{c}\text { Ammonium } \\
(\mu \mathrm{g} \mathrm{N} / \mathrm{g})\end{array}$} \\
\hline & $-\mathrm{AOA}$ & $\overline{+\mathrm{AOA}}$ & $-\mathrm{AOA}^{-}$ & $+\mathrm{AOA}$ & $-\mathrm{AOA}$ & $+\mathrm{AOA}$ \\
\hline $\mathrm{NH}_{4}$ (full) & $56 \pm 3$ & & $8.3 \pm 0.5$ & & $203 \pm 16$ & \\
\hline $\mathrm{NO}_{3}^{4}$ (full) & $119 \pm 4$ & & $3.5 \pm 0.3$ & & $51 \pm 3$ & \\
\hline $\mathrm{NO}_{3}^{3}-\mathrm{P}$ & $77 \pm 4$ & $54 \pm 7$ & $3.4 \pm 0.3$ & $3.9 \pm 0.2$ & $72 \pm 7$ & $69 \pm 7$ \\
\hline $\mathrm{NO}_{3}-\mathrm{K}$ & $89 \pm 7$ & $57 \pm 2$ & $5.5 \pm 0.7$ & $4.2 \pm 0.3$ & $70 \pm 5$ & $79 \pm 5$ \\
\hline $\mathrm{NO}_{3}^{3}-\mathrm{Ca}$ & $68 \pm 5$ & $60 \pm 3$ & $14.3 \pm 1.2$ & $9.9 \pm 0.5$ & $165 \pm 6$ & $81 \pm 6$ \\
\hline $\mathrm{NO}_{3}^{3}-\mathrm{Mg}$ & $91 \pm 3$ & $46 \pm 3$ & $12.7 \pm 0.4$ & $3.2 \pm 0.2$ & $83 \pm 6$ & $45 \pm 1$ \\
\hline
\end{tabular}

${ }^{\mathrm{x}}$ Mean followed by \pm se. Ethylene evolution and ammonium accumulation are expressed on a fresh-weight basis. Treatments of full nutrition + AOA were not included in the experiment.

toxins that enhance stress. In the current experiments, plants grown with ammonium nutrition accumulated more putrescine than spermidine, and plants grown with nitrate nutrition accumulated more spermidine than putrescine. Applying an ethylene synthesis inhibitor suppressed putrescine accumulation but had no apparent effect on spermidine or spermine concentrations. These results indicate that putrescine synthesis probably is caused by ammonium accumulation and the resulting stress.

According to Smith (1990) and Slocum and Weinstein (1990), ammonium accumulation precedes putrescine synthesis. Putrescine biosynthesis may be a metabolic extension of ammonium detoxification by way of glutamate synthesis and the urea cycle (Slocum and Weinstein, 1990). Spermidine and spermine syntheses from putrescine share a common intermediate- $S$-adenosylmethionine-with ethylene synthesis (Smith, 1990). This reaction suggests that polyamine and ethylene syntheses are competing processes. We observed that most nutrient stresses enhanced putrescine accumulation and ethylene evolution but did not affect spermidine and spermine concentrations relative to those occurring in nonstressed plants. Ethylene biosynthesis may have occurred at the expense of spermidine and spermine biosyntheses, even though putrescine accumulation was enhanced by stressinduced ammonium detoxification. A shift in metabolism induced by methionine accumulation from protein hydrolysis may have accelerated ethylene biosynthesis. We propose that environmental stresses, through net protein

Table 4. Concentration of putrescine, spermidine, and spermine as affected by nutrient deficiency and AOA.

\begin{tabular}{|c|c|c|c|c|c|c|}
\hline \multirow{3}{*}{$\begin{array}{l}\text { Nutritional } \\
\text { regime }\end{array}$} & \multicolumn{6}{|c|}{ Measurement (nmol/g dry wt) ${ }^{z}$} \\
\hline & \multicolumn{2}{|c|}{ Putrescine } & \multicolumn{2}{|c|}{ Spermidine } & \multicolumn{2}{|c|}{ Spermine } \\
\hline & $-\mathrm{AOA}$ & $+\mathrm{AOA}$ & $-\mathrm{AOA}$ & $+\mathrm{AOA}$ & $-\mathrm{AOA}$ & $+\mathrm{AOA}$ \\
\hline$\overline{\mathrm{NH}_{4} \text { (full) }}$ & $1091 \pm 194$ & & $829 \pm 306$ & & $280 \pm 89$ & \\
\hline $\mathrm{NO}_{3}^{4}$ (full) & $725 \pm 221$ & & $1152 \pm 286$ & & $222 \pm 39$ & \\
\hline $\mathrm{NO}_{3}^{3}-\mathrm{P}$ & $621 \pm 137$ & $457 \pm 141$ & $689 \pm 215$ & $522 \pm 139$ & $193 \pm 61$ & $199 \pm 70$ \\
\hline $\mathrm{NO}_{3}-\mathrm{K}$ & $1030 \pm 174$ & $637 \pm 188$ & $1118 \pm 319$ & $887 \pm 243$ & $226 \pm 51$ & $216 \pm 85$ \\
\hline $\mathrm{NO}_{3}-\mathrm{Ca}$ & $547 \pm 137$ & $404 \pm 121$ & $629 \pm 92$ & $492 \pm 65$ & $115 \pm 45$ & $130 \pm 55$ \\
\hline $\mathrm{NO}_{3}-\mathrm{Mg}$ & $620 \pm 71$ & $279 \pm 71$ & $1155 \pm 173$ & $790 \pm 176$ & $365 \pm 53$ & $185 \pm 53$ \\
\hline
\end{tabular}

${ }^{2}$ Mean followed by $\pm \mathrm{SE}$. Treatments of full nutrition + AOA were not included in the experiment. creased permeability and loss of cell compartmentalization, and altered auxin transport or metabolism. These physiological disorders may cause free ammonium to be released from the damaged plant tissue. However, the results of ammonium accumulation from the present study and research by others strongly indicate that ammonium accumulation is an early response to environmental stress and that accumulated ammonium stimulates ethylene biosynthesis, which promotes toxic symptom development.

\section{Literature Cited}

Barker, A.V. 1967. Ammonium interactions with proteins. Biochim. Biophys. Acta 168:447-455.

hydrolysis enhancement, cause free ammomonium accumulation may further stimulate protein hydrolysis (Barker, 1967) and accelerate polyamine and ethylene biosynthesis (Corey and Barker, 1989). In turn, ethylene may promote stress-induced symptom development (Kader, 1985; Tingey, 1980).

Lovatt (1990) demonstrated that an increased free ammonium concentration in response to many environmental stresses is a key factor that alters intermediary and secondary $\mathrm{N}$ metabolism in stressed plants. In the present study, even plants grown with nitrate nutrition under stress accumulated more ammonium than nonstressed plants. These results indicate that stress-induced ammonium accumulation is not caused by external ammonium sources but may arise from protein hydrolysis or other internal sources or metabolic process. Barker et al. (1966) found that plants accumulated ammonium under ammonium stress due to protein degradation. Slocum and Weinstein (1990) suggested that environmental stress possibly increases photorespiratory ammonium cycling.

Suppressing ammonium accumulation and ethylene evolution by the ethylene synthesis inhibitor AOA suggested that enhanced ethylene biosynthesis is a factor that causes ammonium accumulation in stressed plants. This action may be related to the autocatalytic effect of ethylene on its own synthesis and catabolic reactions. Kader (1985) stated that the physiological and biochemical effects of ethylene on horticultural crops include increased respiratory and enzyme activity, in-

A. V. R. Volk, and W. A Jackson. 1966. Root environment acidity as a regulatory factor in ammonium assimilation by the bean plant. Plant Physiol. 41:1193-1199.

Basso, L.C. and T.A. Smith. 1974. Effect of mineral deficiency on amine formation in higher plants. Phytochemistry 13:875-883.

Bremner, J.M. 1965. Inorganic forms of nitrogen, $\mathrm{p}$. 1179-1237. In: C.A. Black (ed.). Method of soil analysis, part 2. Agronomy 9, Amer. Soc. of Agron., Madison, Wis.

Corey, K.A. and A.V. Barker. 1989. Ethylene evolution and polyamine accumulation by tomato subjected to interaction stress of ammonium toxicity and potassium deficiency. J. Amer. Soc. Hort. Sci. 114:651-655.

Feng, J. and A.V. Barker. 1992. Ethylene evolution and ammonium accumulation by nutrientstressed tomato plants. J. Plant Nutr. 15:137153.

Flores, H.E. and A.W. Galston. 1982. Analysis of polyamines in higher plant by high performance liquid chromatography. Plant Physiol. 69:701706.

Galston, A.W., R.K. Sawhney, A.F. Tiburcio, N. Hamasaki, T. Oshima, and M. Furuya. 1990. The control of morphogenesis by polyamines, $p$. 224-237. In: H.E. Flores, R.N. Arteca, and J.C. Shannon (eds.). Polyamine and ethylene: Biochemistry, physiology, and interaction. Amer. Soc. of Plant Physiologists, Rockville, Md.

Kader, A.A. 1985. Ethylene-induced senescence and physiological disorders in harvested horticultural crops. HortScience 20:54-57.

Lovatt, C.J. 1990. Stress alters ammonia and arginine metabolism, p. 166-179. In: H.E. Flores, R.N. Arteca, and J.C. Shannon (eds.). Polyamine and ethylene: Biochemistry, physiology, and interaction. Amer. Soc. of Plant Physiologists, Rockville, Md.

Slocum, R.D. and L.H. Weinstein. 1990. Stressinduced putrescine accumulation as a mechanism of ammonium detoxification in cereal leaves, $\mathrm{p}$. 157-165. In: H.E. Flores, R.N. Arteca, and J.C. Shannon (eds.). Polyamine and ethylene: Biochemistry, physiology, and interaction. Amer. Soc. of Plant Physiologists, Rockville, Md.

Smith, T.A. 1990. Plant polyamine-metabolism and function, p. 1-23. In: H.E. Flores, R.N. Arteca, and J.C. Shannon (eds.). Polyamine and ethylene: Biochemistry, physiology, and interaction. Amer.Soc. of Plant Physiologists, Rockville, Md.

Tingey, D.T. 1980. Stress ethylene-A measure of plant response to stress. HortScience 15:630633. 